\title{
THE NATIONAL AVIATION MUSEUM, OTTAWA
}

\author{
By S. L. ROBERTS
}

Department of Northern Affairs and National Resources, Ottawa

$\mathrm{T}$ HE story of Canadian aviation, an important chapter in Canada's national devolopment which many Canadians havo ombellished with thoir distinctive contributions, is presented in the new National Aviation Museum at Ottawa.

Tho National Aviation Musoum, situated in the new Uplands Air Terminal, was opened recently by the Hon. J. Angus MacLean, Minister of Fisheries. Through the displays, visitors can trace the progress of Canadian aviation from the experiments of the pioneers in the early 1900 's to the complox jot and rocket developments of present time.

The basic theme of the Museum is "Canada's Contribution to Aviation, and Aviation's Contribution to Canada". To carry out this theme, reliance could not be placed on the display of historical items alone. These rolics of the early days of the aviation have been placed mostly in the primary display area, which is concentrated on the pioneering days of flight in Canada. The rest of the displays are of the didactic type, using photographs, models and selected samples of actual aircraft and aviation parts, instruments, accessories and equipment to portray the story of civil aviation in Canada.

There are nine distinct sections to the Museum. From the pioneer section visitors pass to the area in which the development of piston-engines, navigation instruments and electronics is presented. The next area illustrates aviation's supporting services-air traffic control, airport construction, weathor, aviation medicine, communications, maintenance and overhaul, search and rescue, and tho radar detection chains in northern Canada. The operations section illustrates the development of commercial airlines and the use of aircraft in photography, mapping, geological survey, forest fire fighting, insecticide spraying, and communications.

The sections dealing with jets, rockets and research demonstrate the increasing complexity of aircraft design and the extent to which aeronautical research has expanded. Two other sections follow, one showing some of the development of the aviation manufacturing industry, and the other the extent that the demand of aviation for new techniques and materials has encouraged the development of Canadian industry and made the country less dependent on imports of manufactured articles.

One rather novel feature is a 'children's museum', where much thought has been given to making the displays interesting and attractive to children. Hero young visitors can learn to identify the parts of aircraft and undorstand their function, and play with small plastic aircraft models on a toy landing field.

One full-sized aircraft, displayed in another part of the building, forms part of the Museum. This is a Aying replica of the Silver Dart, the machine built on Cape Breton Island by the unique aeronautical research group of Canadians and Americans led by the inventor of the telephone, Alexander Graham Bell. The Silver Dart mado the first flight in Canadaand the first flight by a British subject in the Commonwealth--in February 1909, with a Canadian pilot, J. A. D. McCurdy, at the controls. This historic aircraft was duplicated, with a few practical modifications, by L.A.C. Lionel McCaffrey and other airmen of the R.C.A.F. and flown by W/C Paul Hartman at Cape Breton Island in February 1959 in a reenactment of the first flight.

Although space limitations prevent the display of other full-sized aircraft, models of Canadian aircraft types have been provided by British, Canadian and American manufacturers for display in the Museum. The $1 / 24$ scale, as followed in the Science Museum at South Kensington, has been adopted as the standard for the aircraft models, though many of the models given or lent to the Museum are of other scales.

The Museum attempts to provide a clear and comprehensive presentation of aviation in Canada within the limitations of a small area. It is remarkably complete and contains many individual items of great interest. Among those are a 'mock-up' of the Canadian-developed Velvet Glove air-to-air missile,

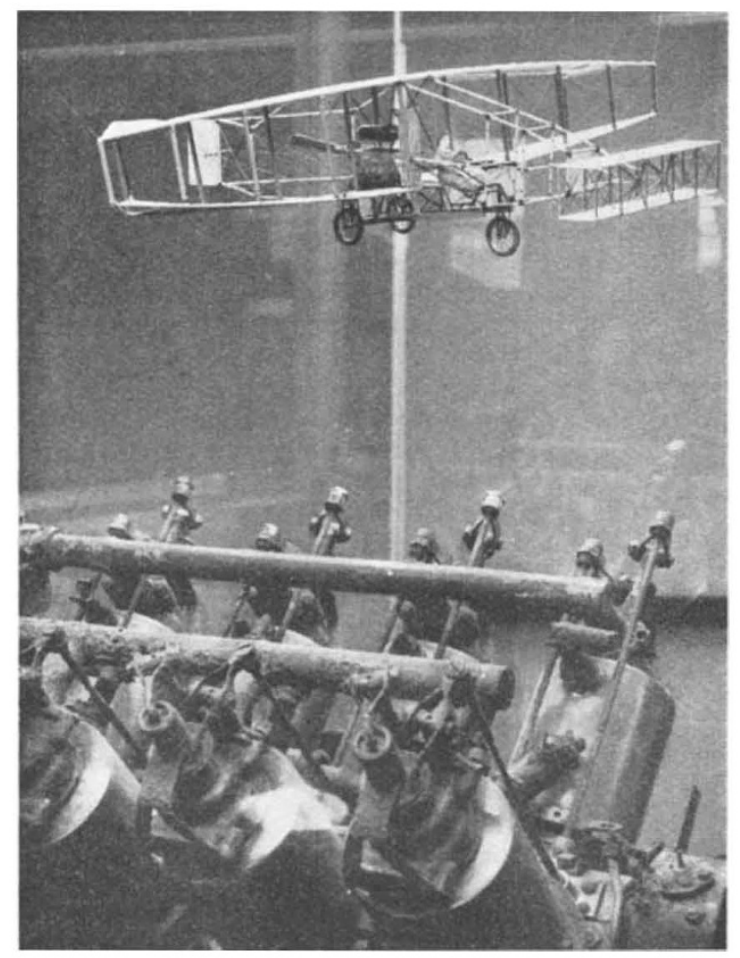

Fig. 1. The original Silver Dart engine and a molel of the aircraft 


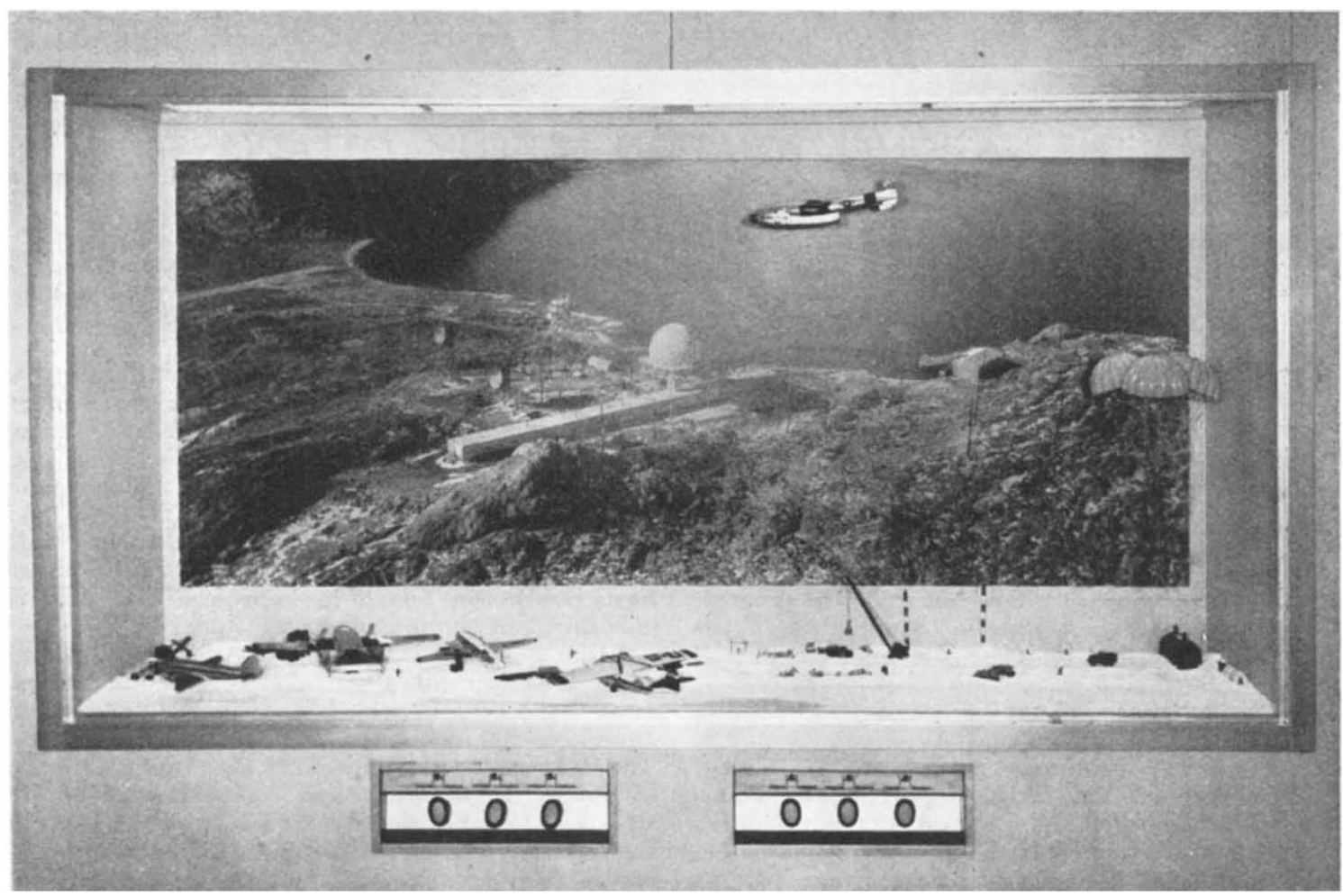

Fig. 2. Model of the Dew Line activities and aireraft used in supplying stations

controllable-pitch propellers invented by the Now Brunswick pioneer Wallace $R$. Turnbull during 1923-27, an operating model of the early wind-tunnel used at the University of Toronto in the 1920's, and a steering wheel from the British airship $R-100$. In appearance, the Museum gains variety by using distinctive colours and surface textures to identify the display areas, and by arranging the walls in an irregular pattern.

In keeping with the technological atmosphere of the Musoum, some individual displays can be set into operation by the public. Repeaters provide a recorded sound narration in French or English to explain the more technical aspects. Among these operating exhibits are demonstrations of the effect of changes in atmospheric pressure on sparking plugs, and of the contrast; of photoclastic stress botween large radii and sharp angles.

The National Aviation Museum of Canada has been a long time in the making. A start was made as early as 1929 , whon J. H. Parkin, now senior consultant to the Division of Mechanical Engineering of the National Research Council, brought a number of aireraft engines and modols of wind tunnels to the National Research Council. In 1932 the Council set up a small aeronautical museum, devoted chiefly to engines, in the baserment of one of its Ottrowa buildings, but this museum was closed carly in the Second World War.

Fortunatoly, the rare itoms from aviation history that had been collected were stored and well preserved through the years. In 1956 an Associate Committeo of the National Research Council was formed, with Goneral A. G. L. MeNaughton as chairman, to study the problems of creating a National
Aviation Museum. Much stimulus was provided by the National Co-ordinating Couneil for the Golden Anniversary of Flight in Canada, a group representing aeronautical and flying associations and organizations which planned the 1959 anniversary programme.

The National Aviation Museum was established with funds provided by the Canadian Government and with funds or displays given by many firms in Canada, Great Britain and the United States. The National Research Council collection scrved as the nucleus of the Musoum, and this material was assembled with the new donations into an organized museum by the staff of the Engine Laboratory, Division of Mechanical Engineering, National Research Council, under the direction of its chicf, M. S. Kuhring.

Although the National Aviation Museum is designated as the first unit of a Canadian Museum of science, it will be some years before permanent accommodation is provided. As a temporary measure the Muscum is suitably located at Ottawa in the new Uplands Air Terminal. From the windows of an observation room which occupies one corner of the Museum, aircraft can be observed landing and takingoff from one of the busiest of Canada's airfields. Air travellers may also enjoy the experienee of visiting this unique aviation museum while waiting for their flights.

The National Aviation Museum is administered by the Department of Northern Affairs and National Resources, the Fedoral department which administers the National Museum of Canada, the Canadian War Museum, and a number of small historical museums throughout the country. 